Bull. Chem. Soc. Ethiop. 2021, 35(1), 161-170.

(c) 2021 Chemical Society of Ethiopia and The Authors

ISSN 1011-3924

DOI: https://dx.doi.org/10.4314/bcse.v35i1.14

Printed in Ethiopia

Online ISSN 1726-801X

\title{
GREEN SYNTHESIS OF MgO NANOPARTICLES USING MORINGA OLEIFERA LEAF AQUEOUS EXTRACT FOR ANTIBACTERIAL ACTIVITY
}

\author{
Awalul Fatiqin ${ }^{1}$, Hanif Amrulloh ${ }^{2 *}$ and Wasinton Simanjuntak ${ }^{3}$ \\ ${ }^{1}$ Department of Biology, Faculty of Science and Technology, Islamic State University of Raden \\ Fatah Palembang, Palembang, South Sumatera, Indonesia \\ ${ }^{2}$ Department of Mathematics Education, Faculty of Tarbiyah, Institute for Islamic Studies \\ Ma' arif NU (IAIMNU) Metro Lampung, Metro, Lampung, Indonesia \\ ${ }^{3}$ Department of Chemistry, Faculty of Mathematics and Natural Science, The Universitas \\ Lampung, Bandar Lampung, Lampung, Indonesia
}

(Received June 28, 2020; Revised March 16, 2021; Accepted March 23, 2021)

\begin{abstract}
Nanoparticle fabrication using plant extracts is an important alternative method because it is nontoxic, biocompatible, and environmentally friendly. In this study, green synthesis of $\mathrm{MgO}$ nanoparticles using Moringa oleifera leaf water extracts was conducted by mixing the extract and a solution of magnesium chloride. The product was characterized using different techniques, i.e. UV-Visible (UV-Vis) spectroscopy, X-ray diffraction (XRD), scanning electron microscopy (SEM) and Fourier transform infrared spectroscopy (FTIR). The UV-Vis spectrum of $\mathrm{MgO}$ nanoparticles shows an absorption at $280 \mathrm{~nm}$. The size of the synthesized $\mathrm{MgO}$ nanoparticles ranges from 20-50 $\mathrm{nm}$. The antibacterial activity of $\mathrm{MgO}$ nanoparticles was seen from the zone of inhibition against Staphylococcus aureus $(6.3 \mathrm{~mm})$ and against Escherichia coli $(6 \mathrm{~mm})$. $\mathrm{MgO}$ nanoparticles have been successfully fabricated using Moringa oleifera leaf aqueous extracts, providing an alternative method for synthesizing $\mathrm{MgO}$ nanoparticles.
\end{abstract}

KEY WORDS: Antibacterial activity, Escherchia coli, MgO nanoparticles, Moringa oleifera, Staphylococcus aureus

\section{INTRODUCTION}

In recent years, a lot of interest has arisen to synthesize nanoparticles of $\mathrm{Fe}, \mathrm{Ni}, \mathrm{Cu}, \mathrm{Ti}$, and $\mathrm{Mg}$ because they have superior properties and can be applied in variousfieldssuch as sensors [1], catalyst [2], and biomedical applications [3-5]. Of all-metal oxide nanoparticles, magnesium oxide $(\mathrm{MgO})$ nanoparticles have good activity for use as an antibacterial. Leung et al. [6] explained that the antibacterial activity of $\mathrm{MgO}$ nanoparticles can be observed based on the absence of reactive oxygen species (ROS). The mechanism of antibacterial activity that occurs is possible by destruction of cell membranes.

Several researchers have synthesized $\mathrm{MgO}$ nanoparticles using several methods, including sol-gel [7], sonochemical [8], co-precipitation [9, 10], and chemical reduction [11]. Green synthesis techniques use reagents that are free of chemicals that are harmful to the environment such as using water solvents or plant extracts $[12,13]$. The use of Moringa leaf extract in the process of synthesis of metal oxide nanoparticles has been widely carried out by previous researchers. Ezhilarasi et al. [3] successfully synthesized nickel oxide nanoparticles (NiO) using Moringa oleifera leaf extract with water and ethanol as asolvent. The synthesized NiO crystal is a face-centered cubic with a crystalsize of $9.69 \mathrm{~nm}$.

The activitities of $\mathrm{MgO}$ against bacteria have been studied by several researchers previously. Mirhosseini and Afzali [14] studied the antibacterial activity of $\mathrm{MgO}$ suspension against Escherichia coli (E. coli) in milk. Scanning using an electron microscope was performed to characterize the morphological changes of the E. coli after antibacterial treatment. The results

*Corresponding author. E-mail: amrulloh.hanif@iaimnumetrolampung.ac.id

This work is licensed under the Creative Commons Attribution 4.0 International License 
obtained indicate that the presence of $\mathrm{MgO}$ combined with pressure can damage cell membranes, resulting in a leakage of the cell contents, and eventually, the bacterial cells die. Das et al. [4] synthesized $\mathrm{MgO}$ nanoparticles using Bauhinia purpurea extract as an antibacterial against Staphylococcus aureus (S. aureus). The antibacterial activity of $\mathrm{MgO}$ was tested through colony forming unit analysis with fluorescence microscope and FE-SEM. The results showed that the $\mathrm{MgO}$ produced had high activity as an antibacterial agent against $S$. aureus with a small dose $(250 \mu \mathrm{g} / \mathrm{mL})$. Amrulloh et al. [15] tested the bioactivity of $\mathrm{MgO}$ nanoparticles prepared using aqueous extract of $M$. oleifera bark. The average particle size of the synthesized $\mathrm{MgO}$ nanoparticles lied between 60-100 $\mathrm{nm}$ using SEM and TEM images and PSA results. MgO NPs synthesized showed good antioxidant activity and antibacterial activity against $S$. aureus, E. faecalis, E. coli and $S$. dysenteriae bacteria.

In this research, the synthesis of $\mathrm{MgO}$ nanoparticles was carried out using $M$. oleifera leaf aqueous extracts and studied the antibacterial activity against $E$. coli and $S$. aureus.

\section{EXPERIMENTAL}

\section{Materials}

Fresh M. oleifera leaf was collected from the plants that grow naturally around the City of Metro, Lampung, Indonesia during September 2019. Laboratory grade magnesium chloride hexahydrate $\left(\mathrm{MgCl}_{2} \cdot 6 \mathrm{H}_{2} \mathrm{O}\right)$, Folin-Ciocalteu reagents, sodium carbonate $\left(\mathrm{Na}_{2} \mathrm{CO}_{3}\right)$, gallic acid, catechin, aluminum chloride $\left(\mathrm{AlCl}_{3}\right)$, sodium nitrite $\left(\mathrm{NaNO}_{2}\right)$, sodium hydroxide $(\mathrm{NaOH})$, and Mueller-Hinton agar were purchased from Merck Sigma-Aldrich Reagent Pte, Singapore. Bacterial cultures (E. coli and $S$. aureus) were obtained from the microbiology laboratory of Airlangga University.

\section{Moringa oleifera leaf extract preparation}

Fresh Moringa oleifera leaf was washed using flowing water, and then dried under direct sunlight, and finally ground into powder and stored at room temperature. M. oleifera leaf extraction was conducted with reference to the method reported in Elumalai, et al. [16] and Das et al. [4]. Moringa leaf powder sample of $4 \mathrm{~g}$ was mixed with $100 \mathrm{~mL}$ of distilled water. The mixture was then heated to $60{ }^{\circ} \mathrm{C}$ for 20 min with stirring until all the Moringa sample powder was evenly mixed. After heating, the solution was allowed to cool and filtered using filter paper (Whatman filter paper), and the filtrate was collected. The resulting filtrate was used as a stock solution for the synthesis of $\mathrm{MgO}$ nanoparticles (fresh extract was used for each synthesis and testing process).

\section{Free radical scavenging activity and antioxidant potential of $M$. Oleifera leaf aqueous extract}

\section{DPPH scavenging ability}

The test method using DPPH (1,1-diphenyl-2-picrylhydrazyl) refers to the research by Das et al. [4]. 200 $\mu \mathrm{L}$ of Moringa extract was mixed with $0.1 \mathrm{mM}$ DPPH dissolved in ethanol and $800 \mu \mathrm{L} 50 \mathrm{mM}$ Tris$\mathrm{HCl}$ buffer ( $\mathrm{pH}$ 7.4). The solution was incubated at room temperature $\left(27-30^{\circ} \mathrm{C}\right)$ for $30 \mathrm{~min}$, then the DPPH free radical reduction activity was determinedby measuring the absorbance at $517 \mathrm{~nm}$ wavelength using a UV-Vis spectrophotometer. Ascorbic acid $(1 \mathrm{mg} / \mathrm{mL})$ was used as a comparison of free radical activity, and the solutions without Moringa/ascorbic acid were used as controls. The activity of anti-free radicals against DPPH (\%) was calculated using the formula 1 [17]: 
DPPH scavening activity $(\%)=\frac{\text { control absorbance-sample absorbance }}{\text { control absorbance }} \times 100 \%$

\section{Total phenolic content}

Total phenolic content of the $M$. oleifera leaf aqueous extract was determined by spectrophotometer using the Folin-Ciocalteu reagent, according to the study by Das et al. [4]. Two $\mathrm{mL}$ of M. oleifera extract was mixed with $10 \mathrm{~mL}$ of Folin-Ciocalteu reagent solution with a concentration of 1/10 in deionized water as a solvent, and left for $2 \mathrm{~min}$. After $2 \mathrm{~min}$ incubation, $8 \mathrm{~mL}$ of $1 \mathrm{M}$ sodium carbonate solution was added to the mixture of extract and Folin-Ciocalteu reagents. The mixture was incubated in a dark room for 2 hours at room temperature. To determine the phenolic levels, the absorbance of the mixture was measured using a UV-Vis spectrophotometer at a wavelength of $765 \mathrm{~nm}$. Standard curve was constructed using gallic acid solutions with a concentration range from 50 to $500 \mu \mathrm{g} / \mathrm{mL}$ as standards. The results obtained showed equivalent levels of gallic acid in $\mu \mathrm{g} / \mathrm{mL}$ unit contained in the samples [18].

\section{Total flavonoid content}

The total flavonoid content of the extract was measured using the colorimetric method with aluminum chloride. One $\mathrm{ml}$ of $M$. oleifera leaf extract was mixed with $4 \mathrm{~mL}$ of distilled water, and the $\mathrm{NaNO}_{2}$ solution with a concentration of $0.3 \%(\mathrm{w} / \mathrm{v})$ was added and left for $5 \mathrm{~min}$. After $5 \mathrm{~min}$ incubation, the mixture was added with a solution of $\mathrm{AlCl}_{3} 0.3 \%(\mathrm{w} / \mathrm{v})$ and then left for $6 \mathrm{~min}$. Then $2 \mathrm{~mL}$ of $1 \mathrm{M}$ $\mathrm{NaOH}$ solution was added, and the final mixture was added with distilled water until the volume of the mixture became $10 \mathrm{~mL}$. The mixture was left for $15 \mathrm{~min}$, and the absorbance value was measured at a wavelength of $570 \mathrm{~nm}$ [14]. Total flavonoid levels of Moringa extracts were determined using a standard curve of catechin solution with a concentration range from 100 to $1000 \mathrm{mg} / \mathrm{L}$.

\section{Green synthesis $\mathrm{MgO}$ nanoparticles}

The synthesis of $\mathrm{MgO}$ nanoparticles was commenced by adding $10 \mathrm{~mL}$ of the extractin to $10 \mathrm{~mL}$ of $1 \mathrm{mM} \mathrm{MgCl} 2$ solution and stirred at $600 \mathrm{rpm}$ at $90{ }^{\circ} \mathrm{C}$. After the temperature of $90{ }^{\circ} \mathrm{C}$ has been reached, $2 \mathrm{M} \mathrm{NaOH}$ solution was added dropwise to the mixture, and the mixture was left for $3 \mathrm{~h}$ aging process in order to optimize the formation of the $\operatorname{Mg}(\mathrm{OH})_{2}$ precipitate. The precipitate formed was separated from the mixture by centrifugation with a rotation of $7500 \mathrm{rpm}$ at room temperature for $20 \mathrm{~min}$ and the precipitate was washed twice using ethanol (99\%). The precipitate was dried using an oven to remove any residual water and ethanol. After drying, the precipitate was calcined at $600{ }^{\circ} \mathrm{C}$ for 5 hours.

\section{MgO nanoparticles characterization}

The synthesis of $\mathrm{MgO}$ nanoparticles was followed by UV-Visible spectrophotometer analysis (Analytic Jena Specord 200 Plus). An aliquot of $1 \mathrm{~mL}$ of reaction mixture was placed in a glass cuvette and the absorbance of the sample was scanned from 200 to $800 \mathrm{~nm}$ wavelength. The $\mathrm{MgO}$ nanoparticles produced were characterized using different instrumental techniques. The surface morphology was studied using scanning electron microscopy (SEM, FEI Inspect-S50). The crystal structure was studied using X-ray diffraction (XRD, PAN Analytical Expert Pro) techniques. To detect surface functional groups, the samples were characterized using a Fourier Transform Infrared spectrophotometer (FTIR, Shimadzu IR Prestige 21). 
Antibacterial activity

The antibacterial activities of $M$. oleifera leaf aqueous extract, $\mathrm{MgO}$ nanoparticles and different antibiotics (Ampicillin, Chloramphenicol, and Erythromycin) were evaluated against gram-negative Escherichia coli and gram-positive Staphylococcus aureus obtained from the microbiology laboratory of Airlangga University using the modified paper disc method of Katata-Seru et al. [19]. Briefly, isolates were grown on nutrient agar at $37^{\circ} \mathrm{C}$ for 18 to $24 \mathrm{~h}$. The bacterial suspensions were then swabbed on the Mueller-Hinton agar (MHA) plates using sterile cotton swabs. Sterile Whatman No 1 paper discs at 6 $\mathrm{mm}$ dimension were impregnated with $\mathrm{MgO}$ nanoparticles. The discs with different antibiotics (Ampicillin, Chloramphenicol, and Erythromycin) located on the plates were maintained as references. The discs were gently pressed in MHA plates and incubated in inverted position for $24 \mathrm{~h}$ at $37^{\circ} \mathrm{C}$ to determine the zone of inhibition.

\section{RESULTS AND DISCUSSION}

Free radical scavenging activity and antioxidant potential of $M$. oleifera leaf aqueous extract

DPPH scavenging ability

Antioxidant activity of the $M$. Oleifera leaf aqueous extract measured by DPPH method is shown in Table 1. A testing anti-free radical activity using DPPH is a must in every test of antioxidant and phytochemical ability of a plant extract [20-22]. The antioxidant activity of $M$. oleifera leaf aqueous extract displays a good DPPH inhibition with $64.60 \pm 0.69 \%$ RSA (radical scavenging activity) as compared ascorbic acid showed around $71.72 \pm 0.56 \%$ inhibition of DPPH.

\section{Total phenolic content}

Gallic acid used as a standard to determine total phenolic content spectrophotometrically (765 $\mathrm{nm})$ [15]. Amount of phenolic compound present in the leaf extract calculated using gallic acid standard curve. Total phenolic content of the M. oleifera leaf aqueous extract of $683.95 \pm 0.74$ GAE per $\mathrm{mL}$ was found. It can be infered from Table 1 that the phenolic content of the leaf extract sample may be responsible for the reduction of $\mathrm{Mg}^{2+}$ ion to form $\mathrm{MgO}$ nanoparticles [23].

\section{Total flavonoid total}

Total flavonoid content was measured spectrophotometrically used aluminium chloride method at $510 \mathrm{~nm}$ [4]. Total flavonoid content of the M. oleifera leaf aqueous extract was found to be $514.08 \pm 0.12 \mu \mathrm{g} \mathrm{CE}$ (catechin equivalent) per $\mathrm{mL}$ (Table 1). This finding is in agreement with report by others which show that flavonoids have antioxidant activity in vitro and also act as antioxidant in vivo [24].

Tabel 1. Free radical scavening activity and antioxidant potential of $M$. oleiferaleaf aqueous extract.

\begin{tabular}{|l|c|c|c|c|c|}
\hline \multirow{2}{*}{ Sample } & \multicolumn{4}{|c|}{ Free radical scavenging activity and antioxidant potential of M. oleifera leaf extract } \\
\cline { 2 - 6 } & $\begin{array}{c}\text { DPPH } \\
\text { scavenging } \\
\text { ability }(\%)\end{array}$ & $\begin{array}{c}\text { Total phenolic } \\
\text { content } \\
\left(\mu \mathrm{g} \mathrm{GAE} \mathrm{mL}^{-1}\right)\end{array}$ & $\begin{array}{c}\text { Total flavonoid } \\
\text { content } \\
\left(\mu \mathrm{g} \mathrm{CE} \mathrm{mL}^{-1}\right)\end{array}$ & $\mathrm{IC}_{50}(\mu \mathrm{g} / \mathrm{mL})$ & $\begin{array}{c}\text { Antioxidant } \\
\text { activity index } \\
(\mathrm{AAI})\end{array}$ \\
\hline Ascorbic acid & $71.72 \pm 0.56$ & - & - & $1.17 \pm 0.43$ & $33.65 \pm 0.72$ \\
\hline $\begin{array}{l}\text { M. oleifera } \text { aqueous } \\
\text { leaf extract }\end{array}$ & $64.60 \pm 0.69$ & $683.95 \pm 0.74$ & $514.08 \pm 0.12$ & $27.52 \pm 0.12$ & $1.43 \pm 0.31$ \\
\hline
\end{tabular}


Synthesis and characterization of nanoparticles $\mathrm{MgO}$

\section{UV-Visible spectroscopy}

Synthesis of $\mathrm{MgO}$ nanoparticles using Moringa oleifera leaf aqueous extract was followed by a change in color during the synthesis process. The color of the solution changed from clear $\left(\mathrm{MgCl}_{2}\right.$ solution) to dark brown after the Moringa extract was added. After adding $\mathrm{NaOH}$, the color of the solution changes to brighter, indicating the formation of $\mathrm{MgO}$ and $\mathrm{Mg}(\mathrm{OH})_{2}$ complexes in the solution. The colloidal mixture was scanned over the wavelength in the range of 200-800 nm, and the UV spectrum produced is shown in Figure 1. As can be seen, the spectrum is characterized by the appearance of the peak at around $280 \mathrm{~nm}$, which confirms the formation of $\mathrm{MgO}$ nanoparticles $[12,15]$.

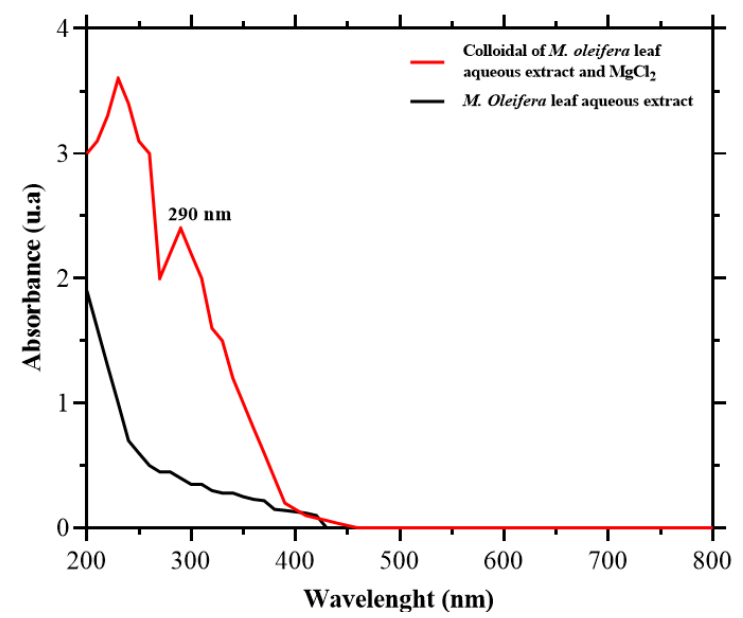

Figure 1.UV-Visible absorption peaks of $M$. oleifera leaf aqueous extract and colloidal of $M$. oleifera leaf aqueous extract and $\mathrm{MgCl}_{2}$.

Besides, the precursor ion $\mathrm{Mg}^{2+}, \mathrm{MgCl}_{2}$ salt does not show a spectrum at the specified wavelength. The existence of a peak of about 280-290 $\mathrm{nm}$ can be attributed to the formation of metal oxide nanoparticles after the addition of plant extracts and $\mathrm{NaOH}$ solution [4]. This phenomenon can be related to the formation of $\mathrm{MgO}$ nanoparticles from their saline solution precursor [25].

$X R D$

The crystalline phase and structure of the synthesized $\mathrm{MgO}$ nanoparticles were investigated using X-ray diffraction techniques to properly study the position of the atoms in the lattice structure. Figure 2 shows the XRD pattern of $\mathrm{MgO}$ nanoparticles. The two highest peaks at the XRD diffractogram are specific for $\mathrm{MgO}$ nanoparticles (at $2 \theta=42.915,62.304$ ) and supported by three small peaks (at $2 \theta=31.636,74.729,78.629$ ). Confirmation of the results obtained is verified using the JCPDS standard XRD data (No: 78-0430). No significant characteristic peaks appear from $\mathrm{Mg}$ or other impurities detected on the diffractogram indicating the high purity of the synthesized $\mathrm{MgO}$ nanoparticles. The average diameter of crystalline (D) was measured using the Scherrer's formula (Equation 2) for the (200) plane obtained at $21.07 \mathrm{~nm}[20,21]$.

Bull. Chem. Soc. Ethiop. 2021, 35(1) 
$D=\frac{K \lambda}{\beta \cos \theta}$

where $\mathrm{K}$ is a constant dimension depending on the specific geometry of the object, $\lambda$ is the wavelength of X-ray radiation, $\beta$ is the full width at halfmaximum (FWHM) of the significant peaks in radians, and $\theta$ is the Bragg's angle [28].

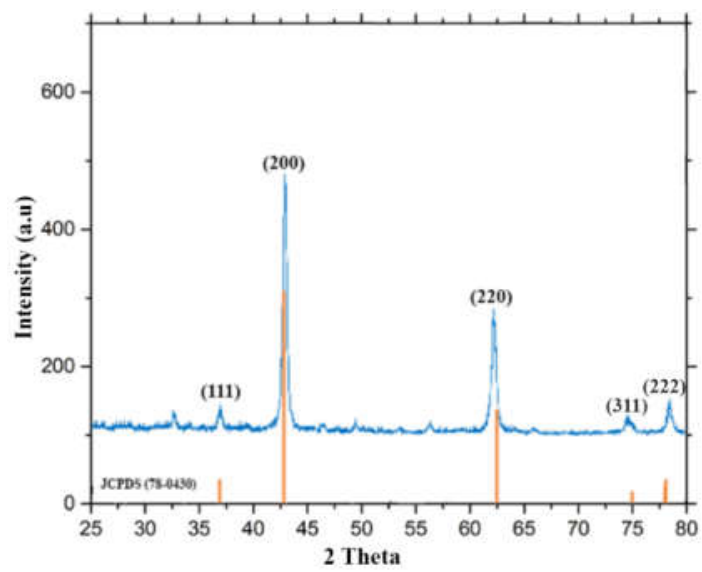

Figure 2. XRD pattern of $\mathrm{MgO}$ nanoparticles.

\section{SEM}

Morphological analysis of $\mathrm{MgO}$ nanoparticles synthesized was carried out using SEM. Figure 3 shows a scanning electron microscopy (SEM) image of $\mathrm{MgO}$ nanoparticles, which shows that the resulting $\mathrm{MgO}$ nanoparticles are in the form of spherical with particle sizes between 20 to 50 $\mathrm{nm}$. Essien et al. [23] synthesized $\mathrm{MgO}$ nanoparticles using the aqueous extract of Chromolaena odorata leaf. UV-visible (UV-Vis) spectrophotometric assessment indicated the formation of $\mathrm{MgO}$ nanoparticles by the presence of a peak at $270 \mathrm{~nm}$, SEM showed good surface properties, energy-dispersive X-ray analysis (EDX) confirmed the presence of $\mathrm{MgO}$ in the sample, transmission electron microscopy (TEM) revealed cubic-shaped $\mathrm{MgO}$ nanoparticles with average size of $12.3 \mathrm{~nm}, \mathrm{X}$-ray diffractometry (XRD) confirmed the formation of $\mathrm{MgO}$ phase. Amrulloh et al. [15] synthesize $\mathrm{MgO}$ nanoparticles using $M$. oleifera bark aqueous extract as green agent. The spherical crystal structure of $\mathrm{MgO}$ nanoparticle was confirmed using XRD and SEM analysis. The average particle size of the synthesized MgO nanoparticles between 60-100 $\mathrm{nm}$ was revealed by SEM and TEM images and PSA results.

\section{FTIR}

FTIR analysis was carried out to investigate absorbed molecules or functional groups on the surface of $\mathrm{MgO}$ nanoparticles synthesized using M. oleifera leaf aqueous extract. Also, it can be used in investigating the mechanism of synthesis of $\mathrm{MgO}$ nanoparticles using biological compounds. Figure 4 shows the FTIR spectra of $\mathrm{MgO}$ nanoparticle samples synthesized, displaying sharp absorption bands at wavenumbersof $1190 \mathrm{~cm}^{-1}$ and $1460 \mathrm{~cm}^{-1}$, which show the presence of Mg-O interactions [29]. Also, smallbands in the area of 2000-2400 $\mathrm{cm}^{-1}$ indicate a stretch of C-H of the remaining organic compounds and a band in the region of 3500 to 3800 $\mathrm{cm}^{-1}$, which is related to the stretching of the N-H group [23]. From the spectrum, it can be concluded that the $\mathrm{MgO}$ nanoparticles produced on the surface do not contain other molecules or functional groups. 

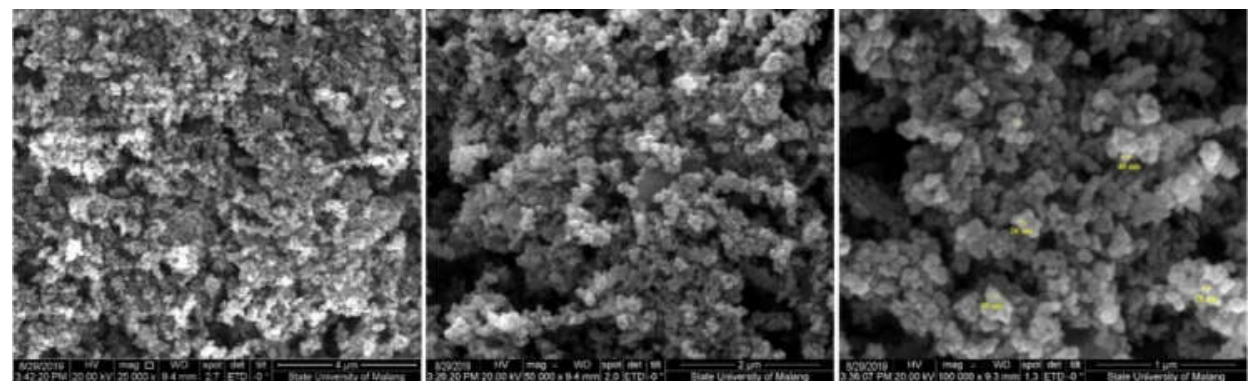

Figure 3. SEM image of $\mathrm{MgO}$ nanoparticles.

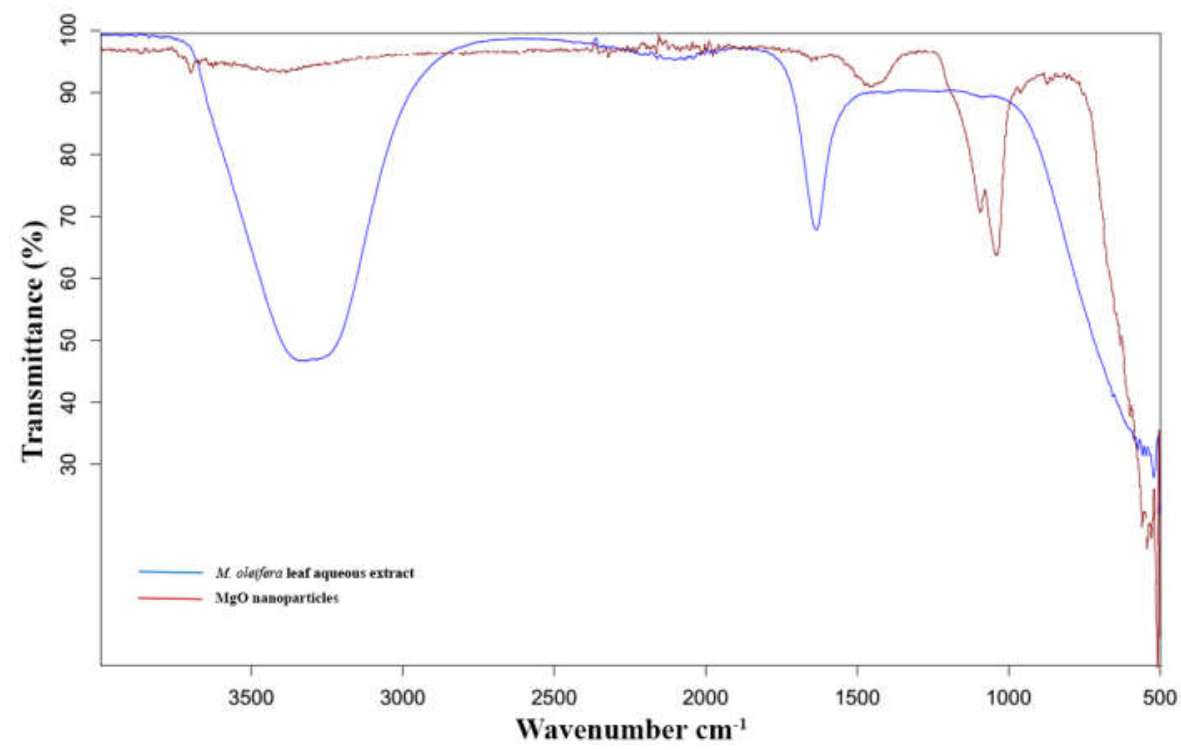

Figure 4. FTIR spectra of $M$. oleifera extract and $\mathrm{MgO}$ nanoparticles.

\section{Antibacterial activity of $\mathrm{MgO}$ nanoparticles}

The relative antibacterial activity of $\mathrm{MgO}$ nanoparticles was evaluated against pathogenic bacteria $S$. aureus (gram-positive) and E. coli (gram-negative) using the impregnation method. The zone of inhibition results $(\mathrm{mm})$ from antibacterial testing of $\mathrm{MgO}$ nanoparticle samples and standard antibiotics (ampicillin, chloramphenicol, erythromycin) shown in Table 2. MgO nanoparticles have antibacterial activity against $S$. aureus and $E$. coli with a zone of inhibition against gram-positive bacteria is larger than that for gram-negative bacteria.

The green synthesized magnesium oxide nanoparticles demonstrated its antibacterial activity against both gram-positive and gram-negative bacteria, it was found that the antibacterial effect of $\mathrm{MgO}$ nanoparticles was higher against gram-positive ( $S$. aureus) bacteria than that against gram-negative (E. coli), with the inhibition zones of $6.3 \mathrm{~mm}$ and $6 \mathrm{~mm}$, respectively (Table 2). The difference between gram-positive and gram-negative bacteria is mainly in the structure of their cell walls. Gram-positive bacteria have a thick layer of peptidoglycan without an outer 
membrane and contain teichoic acid. In contrast, gram-negative bacteria have a thin layer of peptidoglycan with an outer membrane that contains lipopolysaccharides [33]. The experimental results demonstrate that the synthesized $\mathrm{MgO}$ nanoparticles possess a moderate activity against the tested pathogens compared to the standard drug. The diameter of the zone inhibition reflects the magnitude of the susceptibility of microbes. Compared with other metal oxide nanoparticles, synthesized $\mathrm{MgO}$ nanoparticles have larger zone inhibition than those of $\mathrm{CuO}$ and $\mathrm{ZnO}$ nanoparticles, but smaller than that of $\mathrm{Fe}_{2} \mathrm{O}_{3}$ nanoparticles.

Table 2. Antibacterial activity.

\begin{tabular}{|l|l|c|c|}
\hline Metal oxide nanoparticles & Bacteria & Zone inhibition $(\mathrm{mm})$ & Reference \\
\hline $\mathrm{MgO}$ & S. aureus & 6.3 & $*$ \\
\hline $\mathrm{MgO}$ & E. coli & 6 & $*$ \\
\hline $\mathrm{Fe}_{2} \mathrm{O}_{3}$ & S. aureus & 13 & {$[30]$} \\
\hline $\mathrm{Fe}_{2} \mathrm{O}_{3}$ & E. coli & 12 & {$[31]$} \\
\hline $\mathrm{CuO}$ & S. aureus & 3.2 & {$[32]$} \\
\hline $\mathrm{CuO}$ & E. coli & 4 & {$[32]$} \\
\hline $\mathrm{ZnO}$ & S. aureus & 3 & {$[32]$} \\
\hline $\mathrm{ZnO}$ & E. coli & 3.5 & {$[32]$} \\
\hline M. oleifera leaf & S. aureus & 3.2 & $*$ \\
\hline M. oleifera leaf & E. coli & 2.8 & $*$ \\
\hline Ampicillin & S. aureus & 10 & $*$ \\
\hline Ampicillin & E. coli & 17 & $*$ \\
\hline Chloramphenicol & S. aureus & 7.7 & $*$ \\
\hline Chloramphenicol & E. coli & 11 & $*$ \\
\hline Erythromycin & S. aureus & 4.3 & $*$ \\
\hline Erythromycin & E. coli & 12 & $*$ \\
\hline
\end{tabular}

*Present work.

\section{CONCLUSION}

Green synthesis of $\mathrm{MgO}$ nanoparticles using plant extracts is a good alternative in the synthesis of a metal oxide nanomaterial. The results obtained in this study show that $\mathrm{MgO}$ nanoparticles can be produced using Moringa oleifera leaf aqueous extracts. The synthesized $\mathrm{MgO}$ nanoparticles were studied for their optical and structural properties by using UV-Visible spectroscopy, FTIR spectroscopy, X-ray diffraction technique and SEM analysis. In UV-Visible spectrum, the existence of $\mathrm{MgO}$ is indicated by the presence of a characteristic absorption at 290 $\mathrm{nm}$. The FTIR analysis shows no functional groups other than those associated with $\mathrm{MgO}$, suggesting a high purity of the sample. XRD and SEM studies confirmed the formation of nanoparticles of spherical shape with the particle size between 20 to $50 \mathrm{~nm}$. The antibacterial experiments against gram-positive $(S$. aureus) and gram-negative $(E$. coli) bacteria demonstrated the potential of $\mathrm{MgO}$ nanoparticles as antibacterial agent for both $S$. aureus and E. coli.

\section{ACKNOWLEDGMENTS}

This research was supported by the Ministry of Religious Affairs Republic Indonesia through collaboration research BOPTN UIN Raden Fatah Palembang No: B-383/Un.09/PP.06/05/2019 and Lembaga Penelitian dan Pengabdian Masyarakat (LP2M) Institute for Islamic Studies Ma' arif NU (IAIMNU) No: 07/0105/IAIMNU/LPM/XI/2019. Furthermore, acknowledgment is also expressed for the full support from Laboratorium Sentral Mineral \& Material Maju Universitas Negeri Malang for technical contributions on the research projects. 


\section{REFERENCES}

1. Zhu, L.; Zeng, W. Room-temperature gas sensing of ZnO-based gas sensor: A review. Sens. Actuators, A Phys. 2017, 267, 242-261.

2. Jin, H.; Zhao, X.; Wu, Z.; Cao, C.; Guo, L. Supercritical water synthesis of nano-particle catalyst on $\mathrm{TiO}_{2}$ and its application in supercritical water gasification of biomass. J. Exp. Nanosci. 2017, 12, 72-82.

3. Ezhilarasi, A.A.; Vijaya, J.J.; Kaviyarasu, K.; Maaza, M.; Ayeshamariam, A.; Kennedy, L.J. Green synthesis of NiO nanoparticles using Moringa oleifera extract and their biomedical applications: Cytotoxicity effect of nanoparticles against HT-29 cancer cells. J. Photochem. Photobiol. B Biol. 2016, 164, 352-360.

4. Das, B.; Moumita, S.; Ghosh, S.; Khan, M.I.; Indira, D.; Jayabalan, R.; Tripathy, S.K.; Mishra, A.; Balasubramanian, P. Biosynthesis of magnesium oxide $(\mathrm{MgO})$ nanoflakes by using leaf extract of Bauhinia purpurea and evaluation of its antibacterial property against Staphylococcus aureus. Mater. Sci. Eng. C 2018, 91, 436-444.

5. Amrulloh, H.; Fatiqin, A. Sintesis Nanopartikel MgO Menggunakan Ekstrak Daun Kelor (Moringa oleifera) dan Uji Aktivitas Antibakteri Terhadap Escherchia coli dan Staphylococcus aureus, 1st ed., Pustaka Learning Center: Malang, Indonesia; 2020; p 145.

6. Leung, Y.H.; Ng, A.M.C.; Xu, X.; Shen, Z.; Gethings, L.A.; Wong, M.T.; Chan, C.M.N.; Guo, M.Y.; Ng, Y.H.; Djurišić, A.B.; Lee, P.K.H., Chan, W.K.; Yu, L.H.; Phillips, D.L.; Ma, A.P.Y.; Leung, F.C.C. Mechanisms of antibacterial activity of MgO: Non-ros mediated toxicity of MgO nanoparticles towards Escherichia coli. Small. 2014, 10, 1171-1183.

7. Patil, A.B.; Bhanage, B.M. Novel and green approach for the nanocrystalline magnesium oxide synthesis and its catalytic performance in Claisen-Schmidt condensation. Catal. Commun. 2013, 36, 79-83.

8. Pilarska, A.A.; Klapiszewski, Ł.; Jesionowski, T. Recent development in the synthesis, modification and application of $\mathrm{Mg}(\mathrm{OH})_{2}$ and $\mathrm{MgO}$ : A review. Powder Technol. 2017, 319 , 373-407.

9. Park,J.-W.; Lee, W.-K.; Lee, C.-H. Preparation of nano-magnesium oxide from seawater bittern using decarboxylation/precipitation method.Mol. Cryst. Liq. Cryst.2016, 636, 142148.

10. Amrulloh, H.; Simanjuntak, W.; Situmeang, R.T.M.; Sagala, S.L.; Bramawanto, R.; Fatiqin, A.; Nahrowi, R.; Zuniati, M. Preparation of nano-magnesium oxide from Indonesia local seawater bittern using the electrochemical method. Inorg. Nano-Metal Chem. 2020, 50, 693698.

11. Gudikandula, K.; Maringanti, S.C. Synthesis of silver nanoparticles by chemical and biological methods and their antimicrobial properties. J. Exp. Nanosci. 2016, 11, 714-721.

12. Moorthy, S.K.; Ashok, C.H.; Rao, K.V.; Viswanathan, C. Synthesis and characterization of Mgo nanoparticles by neem leaves through green method. Mater. Today Proc. 2015, 2 , 4360-4368.

13. Manjula, R.; Thenmozhi, M.; Thilagavathi, S.; Srinivasan, R.; Kathirvel, A. Green synthesis and characterization of manganese oxide nanoparticles from Gardenia resinifera leaves. Mater. Today Proc. 019, 26, 3559-3563.

14. Mirhosseini, M.; Afzali, M. Investigation into the antibacterial behavior of suspensions of magnesium oxide nanoparticles in combination with nisin and heat against Escherichia coli and Staphylococcus aureus in milk. Food Control 2016, 68, 208-215.

15. Amrulloh, H.; Fatiqin, A.; Simanjuntak, W.; Afriyani, H.; Annissa, A. Antioxidant and antibacterial activities of magnesium oxide nanoparticles prepared using aqueous extract of Moringa oleifera bark as green agents. J. Multidiscip. Appl. Nat. Sci. 2021, 1, 44-53.

16. Elumalai, K.; Velmurugan, S.; Ravi, S.; Kathiravan, V.; Ashokkumar, S. Green synthesis of zinc oxide nanoparticles using Moringa oleifera leaf extract and evaluation of its 
antimicrobial activity. Spectrochim. Acta - Part A Mol. Biomol. Spectrosc. 2015, 143, 158164.

17. Amrulloh, H.; Fatiqin, A.; Simanjuntak, W.; Afriyani, H.; Annissa, A. Bioactivities of nanoscale magnesium oxide prepared using aqueous extract of Moringa oleifera leaves as green agent. Adv. Nat. Sci. Nanosci. Nanotechnol. 2021, 12, 015006.

18. Baba, S.A.; Malik, S.A. Determination of total phenolic and flavonoid content, antimicrobial and antioxidant activity of a root extract of Arisaema jacquemontii Blume. J. Taibah Univ. Sci. 2015, 9, 449-454.

19. Katata-Seru, L.; Moremedi, T.; Aremu, O.S.; Bahadur, I. Green synthesis of iron nanoparticles using Moringa oleifera extracts and their applications: Removal of nitrate from water and antibacterial activity against Escherichia coli. J. Mol. Liq. 2018, 256, 296304.

20. Sridhar, K.; Charles, A.L. In vitro antioxidant activity of Kyoho grape extracts in DPPH and ABTS assays: Estimation methods for $\mathrm{EC}_{50}$ using advanced statistical programs. Food Chem. 2019, 275, 41-49.

21. Aini, F.; Maritsa, H.; Riany, H. Antioxidant activity of nipah endophytic fungi (Nypha fruticans Wurmb) from Tanjung Jabung Timur Jambi. J. Biota 2019, 5, 104-109.

22. Kurniawan, Y.S.; Priyangga, K.T.A.; Krisbiantoro, P.A.; Imawan, A.C. Green chemistry influences in organic synthesis: A review. J. Multidiscip. Appl. Nat. Sci. 2021, 1, 1-12.

23. Essien, E.R.; Atasie, V.N.; Oyebanji, T.O.; Nwude, D.O. Biomimetic synthesis of magnesium oxide nanoparticles using Chromolaena odorata (L.) leaf extract. Chem. Pap. 2020, 74, 2101-2109.

24. Ma, Z.F.; Ahmad, J.; Zhang, H.; Khan, I.; Muhammad, S. Evaluation of phytochemical and medicinal properties of Moringa (Moringa oleifera) as a potential functional food. South African J. Bot. 2020, 129, 40-46.

25. Sharma, G.; Soni, R.; Jasuja, N.D. Phytoassisted synthesis of magnesium oxide nanoparticles with Swertia chirayaita. J. Taibah Univ. Sci. 2017, 11, 471-477.

26. Rezaei, M.; Khajenoori, M.; Nematollahi, B. Preparation of nanocrystalline MgO by surfactant assisted precipitation method. Mater. Res. Bull. 2011, 46, 1632-1637.

27. Mageshwari, K.; Mali, S.S.; Sathyamoorthy, R.; Patil, P.S. Template-free synthesis of MgO nanoparticles for effective photocatalytic applications. Powder Technol. 2013, 249, 456462.

28. Amrulloh, H.; Simanjuntak, W.; Situmeang, R.T.M.; Sagala, S.L.; Bramawanto, R.; Nahrowi, R. Effect of Dilution and electrolysis time on recovery of $\mathrm{Mg}^{2+}$ as $\mathrm{Mg}(\mathrm{OH})_{2}$ from bittern by electrochemical method. J. Pure Appl. Chem. Res. 2019, 8, 87-95.

29. Gawande, M.B.; Branco, P.S.; Parghi, K.; Shrikhande, J.J.; Pandey, R.K.; Ghumman, C.A.A.; Bundaleski, N.; Teodoro, O.M.N.D.; Jayaram, R.V. Synthesis and characterization of versatile $\mathrm{MgO}-\mathrm{ZrO}_{2}$ mixed metal oxide nanoparticles and their applications. Catal. Sci. Technol. 2011, 1, 1653-1664.

30. Pallela, P.N.V.K.; Ummey, S.; Ruddaraju, L.K.; Gadi, S.; Cherukuri, C.S.L.; Barla, S.; Pammi, S.V.N. Antibacterial efficacy of green synthesized $\alpha$-Fe2O3 nanoparticles using Sida cordifolia plant extract. Heliyon 2019, 5, e02765.

31. Yoonus, J.; Resmi, R.; Beena, B. Evaluation of antibacterial and anticancer activity of green synthesized iron oxide $\left(\alpha-\mathrm{Fe}_{2} \mathrm{O}_{3}\right)$ nanoparticles. Mater. Today Proc. 2021.

32. Dadi, R.; Azouani, R.; Traore, M.; Mielcarek, C.; Kanaev, A. Antibacterial activity of ZnO and $\mathrm{CuO}$ nanoparticles against gram positive and gram negative strains. Mater. Sci. Eng. C 2019, 104, 109968.

33. Nguyen, N.Y.T.; Grelling, N.; Wetteland, C.L.; Rosario, R.; Liu, H. Antimicrobial activities and mechanisms of magnesium oxide nanoparticles $(\mathrm{nMgO})$ against pathogenic bacteria, yeasts, and biofilms. Sci. Rep. 2018, 8, 16260. 